Original Research Paper

\title{
Amphetamine Stimulates Protein Kinase and Calcium Influx to Increase Corticosterone and Aldosterone Secretion from Male Rat Adrenal Cells
}

\author{
${ }^{1 *}$ Ling-Ling Chang, ${ }^{2}$ Wan-Song Alfred Wun, ${ }^{3}$ Cai-Yun Jian and ${ }^{3,4,5,6 *}$ Paulus S. Wang \\ ${ }^{1}$ Department of Chemical and Materials Engineering, Chinese Culture University, Taipei, 11114, Taiwan \\ ${ }^{2}$ Aspire Fertility, Arcadia, California 91007, USA \\ ${ }^{3}$ Department of Physiology, School of Medicine, National Yang-Ming University, Taipei 11221, Taiwan \\ ${ }^{4}$ Graduate Institute of Biomedical Sciences, China Medical University, Taichung 40402, Taiwan \\ ${ }^{5}$ Department of Biotechnology, College of Health Science, Asia University, Taichung 41354, Taiwan \\ ${ }^{6}$ Department of Medical Research, Taipei Veterans General Hospital, Taipei 11217, Taiwan, ROC, Taiwan
}

Article history

Received: 20-11-2020

Revised: 08-03-2021

Accepted: 09-03-2021

Corresponding Author:

Ling-Ling Chang

Department of Chemical and

Materials Engineering,

Chinese Culture University,

Shih-Lin, Taipei 11114,

Taiwan, R.O.C., Taiwan

Email: 1lchiang@ulive.pccu.edu.tw

*These authors contributed equally to this work

\begin{abstract}
Amphetamine is a potent central nervous system stimulant. Clinical trials have demonstrated that in healthy adults, low (therapeutic) doses of amphetamine can improve i.e., cognition, memory, attention behavior. An amphetamine overdose can affect cardiovascular, central nervous system, musculoskeletal, respiratory, urinary, or sexual function. Furthermore, amphetamine can activate the hypothalamic-pituitary-adrenal axis to increase glucocorticoids and mineralocorticoids released from adrenal. The object of this research was to find out the effect of amphetamine in vivo and in vitro on the production of corticosterone and aldosterone by Zona Fasciculata-Reticularis (ZFR) cells and Zona Glomerulosa (ZG) cells from male rats. For the in vivo study, the rats were given intraperitoneal injections of saline ( $1 \mathrm{ml} / \mathrm{kg} /$ day, group 1), amphetamine $(1 \mathrm{mg} / \mathrm{ml} / \mathrm{kg} /$ day, group 2$)$, or amphetamine $(5 \mathrm{mg} / \mathrm{ml} / \mathrm{kg} /$ day, group 3$)$ for 7 days and then the ZFR or ZG cells from the sacrificed rats were incubated with other drugs. For the in vitro study, the adrenal cells of ZFR or ZG from untreated rats were incubated with amphetamine combined with other drugs. The corticosterone and aldosterone concentrations in samples of the medium were measured using radioimmunoassay. This in vitro and in vivo study illustrated that amphetamine can increase corticosterone secretion by ZFR cells and aldosterone secretion by ZG cells from male rats.
\end{abstract}

Keywords: Amphetamine, Corticosterone, Aldosterone

\section{Introduction}

Abuse of amphetamine-type Central Nervous System (CNS) stimulants is reaching an epidemic level around the world (United Nations Office on Drugs and Crime, 2010). Bazmi et al. (2017) found that Iranian patients with cardiovascular complications were usually amphetamine abusers. Phupong and Darojn (2007) found that the pregnant abusing amphetamine experienced more obstetric symptoms than non-drug abusers. Berman et al. (2008) found that amphetamine abuse causes brain structural abnormalities. Benitez-López et al. (2019) found that after abstinence for 6 months the amphetamine consumers still failed in stress regulation and inhibitory control. In the medical dose range (e.g., in the treatment of obesity, attention deficit/hyperactivity disorder, or narcolepsy), amphetamine brings about mood and executive function changes, such as inducing good mood and the evolution of brain executive function. Very high-dose amphetamine causes damage to the dopamine system and nervous system in certain animals (Berman et al., 2008; Carvalho et al., 2012).

The Hypothalamic-Pituitary-Adrenal (HPA) axis is altered by both physiological and psychological processes to pathological condition as drug addiction, for example, involving amphetamines, cannabinoids, cocaine, ethanol, nicotine, or opiates (Charmandari et al., 2005; Koob, 2008; Zuloaga et al., 2015). Armario (2010) proposed that HPA axis can be activated by cocaine, amphetamine and its derivatives to increase levels of brain monoamines. It is well documented that amphetamine indirectly acts on the CNS, which stimulates the release of 
dopamine in neural system (Dluzen and Ramirez, 1990a; 1990b; Folgering et al., 2019) to increase prolactin release (Raptis et al., 2004). Chen et al. (2003) showed that amphetamine can enhance progesterone production from MA-10 cells. Seibert et al. (2014) showed that 3,4methylenedioxy-methamphetamine conditioned on no other stressors significantly stimulates the HPA axis increasing the levels of plasma concentration of corticosterone, cortisol, 11-deoxycorticosterone, 11dehydrocorticosterone and aldosterone. Their study explored whether amphetamine could stimulate rat adrenal cells to release corticosterone and aldosterone. The mechanism of amphetamine's effect on ZFR and ZG release of corticosteroids was also examined.

Along with corticosteroid release, the mechanisms by which amphetamine mediates steroid release have been examined. Two important mechanisms are (1) adenylate cyclase activation, increasing cAMP concentration, which activates Protein Kinase A (PKA) (Gold, 2019; Ould Amer and Hebert-Chatelain, 2018); and (2) an elevation of cytosolic free calcium via $\mathrm{Ca}^{2+}$ entry from the extracellular space and/or via $\mathrm{Ca}^{2+}$ mobilization from a sequestered intracellular $\mathrm{Ca}^{2+}$ pool, which activates protein kinase $\mathrm{C}$ or $\mathrm{Ca}^{2+}$-calmodulin kinase (Anderson and Kane, 1998; Hughes et al., 1990). Because amphetamine can be ingested orally or by injection or smoking, it might interfere with the CNS or HPA axis to affect physiology. Here we explore the effects of amphetamine on adrenal cells both in vitro and in vivo. To my understanding, this is the first study to examine the direct effects of amphetamine on adrenal cells.

\section{Materials and Methods}

\section{Chemicals}

A23187 (calcium ionophore), Adrenocorticotropic Hormone (ACTH, which increases the production and secretion of cortisol from the cortex of the adrenal gland), amphetamine, angiotensin II (AngII, which stimulates the secretion of aldosterone from the adrenal gland), Bovine Serum Albumin (BSA, a component of KRBGA medium), 8-Br-cyclic AMP (8-Br-cAMP, cAMP analog), Cyclopiazonic Acid (CPA, specific inhibitor of SERCA ATPase in intracellular $\mathrm{Ca}^{2+}$ storage sites), deoxycorticosterone (a precursor for the synthesis of cortisol), Forskolin (FSK, an adenylate cyclase agonist) and H89 (a protein kinase A inhibitor) were bought from Sigma Chemical Co. (St. Louis, MO, USA). Except BSA and deoxycorticosterone, the above drugs were dissolved in water as stock solutions. Deoxycorticosterone was dissolved in ethanol as a stock solution. When both stock solutions challenging cells, they were diluted in KrebsRinger bicarbonate buffer with $3.6 \mathrm{mM} \mathrm{K} \mathrm{K}^{+}, 11.1 \mathrm{mM}$ glucose, $0.2 \%$ BSA medium (KRBGA). $\left[{ }^{3} \mathrm{H}\right]$-aldosterone and $\left[{ }^{3} \mathrm{H}\right]$-corticosterone were bought from Amersham Life Science (Buckinghamshire, UK).

\section{Animals}

The National Yang-Ming University supplied Sprague-Dawley male rats weighing 300-350 g (age: 2 months). Those were housed conditioned on temperature control at $22 \pm 1^{\circ} \mathrm{C}$ and light control with on at 6:00 am and off at 8:00 pm. Food and water were supplied ad libitum. For the in vivo study, rats were randomly divided into three groups. Rats received intraperitoneal injections of saline $(1 \mathrm{ml} / \mathrm{kg} / \mathrm{day}$, group 1), amphetamine (1 $\mathrm{mg} / \mathrm{ml} / \mathrm{kg} / \mathrm{day}$, group 2$)$, or amphetamine (5 mg/ml/kg/day, group 3), respectively, for 7 days. The next morning after the last injection, all rats were sacrificed. To avoid variation caused by the adrenal rhythm, the sacrifice of rats started at 8:00 am and followed a specific pattern. The pattern was to sacrifice a rat from group 1 , followed by a rat from group 2, then a rat from group 3 and repeat until done. The whole process was complete before 10:00 am.

The animal protocols adopted in this study were approved by the Institutional Animal Care and Use Committee of the National Yang-Ming University. All animals were treated in humane care complying with the Principles of Laboratory Animal Care and the Guide for the Care and Use of Laboratory Animals, published by the National Science Council, Taiwan, ROC.

\section{Preparation of Zona Fasciculata-Reticularis (ZFR) and Zona Glomerulosa (ZG) Cells for Cell Culture}

The amphetamine treatment included both an in vivo and an in vitro model. The in vivo model included groups 1, 2 and 3 described above. For the in vitro model, adrenal glands were obtained from rats without any treatment. Preparation of ZFR and ZG cells from the glands followed our previous report (Lo et al., 1998; Chang et al., 2008). In brief, adrenal glands (from the in vivo and in vitro models) were taken with adipose tissues being removed then kept in ice-cold $0.9 \%$ (w/v) $\mathrm{NaCl}$ solution. The glands were separated into capsule (mainly zona glomerulosa) and inner zone (mainly zona fasciculata-reticularis) fractions. The inner zone or capsule fractions from 10-20 adrenals coming from the same group of rats were put together as a single dispersion. The cells $\left(5 \times 10^{4}\right.$ cells $\left./ \mathrm{ml}\right)$ were pre-incubated with KRBGA medium for $1 \mathrm{~h}$ at $37^{\circ} \mathrm{C}$ in a shaker bath $(50$ cycles/min) aerated with $95 \% \mathrm{O}_{2}$ and $5 \% \mathrm{CO}_{2}$. Then, the supernatant was dropped out after centrifugation at $200 \times g$ for $10 \mathrm{~min}$. Finally, the cells were suspended and incubated with fresh incubation medium for 1,4 , or $24 \mathrm{~h}$ and centrifugaled, respectively. The medium was stored at $-20^{\circ} \mathrm{C}$ for corticosterone or aldosterone Radioimmunoassay (RIA).

\section{RIA of Corticosterone and Aldosterone}

Concentrations of corticosterone in the media were determined by RIA (Chang et al., 2002; Lo et al., 1998). The RIA with antiserum PSW\#4-9 was set up to measure 
plasma corticosterone levels. The sensitivity of the corticosterone RIA was $5 \mathrm{pg} /$ tube and the variation of intra- and inter-assay coefficients were $3.3 \%(\mathrm{n}=5)$ and $9.2 \%(n=4)$, respectively.

The concentration of aldosterone in the medium was determined by RIA (Kau et al., 2000). A RIA with the antiserum JJC-088 was set up to measure plasma aldosterone levels. The sensitivity of the aldosterone RIA was $4 \mathrm{pg} /$ tube. The variation of intra-(assay) and inter-assay coefficients were $3.9 \%(\mathrm{n}=5)$ and $8.2 \%(\mathrm{n}=$ $4)$, respectively.

\section{Statistical Analysis}

The results are shown as the mean \pm S.E.M. A oneway Analysis Of Variance (ANOVA) test (Steel and Torrie, 1960) was used to assess differences among the mean values of all groups. A t-test compares the difference between groups conditioned on significant difference being established. The result of $P<0.05$ was statistically significant.

\section{Results}

\section{In Vitro Study}

Effects of Amphetamine with ACTH, Forsolin, 8Br-cAMP, or Deoxycorticosterone on the Release of Corticosterone by Rat ZFR Cells

Incubation of ZFR cells for $4 \mathrm{~h}$ with ACTH $\left(10^{-9} \mathrm{M}\right)$, forskolin $\left(10^{-5} \mathrm{M}\right), \quad 8$-Br-cAMP $\left(10^{-5} \mathrm{M}\right)$, or deoxycorticosterone $\left(10^{-6} \mathrm{M}\right)$ enhanced corticosterone release (Fig. 1A and 1B; $P<0.01$ ). Incubation of these reagents (except ACTH and forskolin) with amphetamine $\left(10^{-7}-10^{-5} \mathrm{M}\right)$ caused dose proportionally dependent increment of corticosterone release from ZFR cells (Fig. 1A and $1 \mathrm{~B} ; P<0.05$ or 0.01$)$. Amphetamine did not increase the
ACTH- or forskolin-induced corticosterone release from ZFR cells. It could be that the ACTH- or forskolin-induced corticosterone arrived at the plateau level after ZFR cells $4 \mathrm{~h}$ incubation with ACTH or forskolin, which makes the effects of amphetamine disappeared.

Effects of Amphetamine with AngII, $\mathrm{KCl}, \mathrm{CPA}$, or A23187 on the Release of Aldosterone by Rat ZG Cells in Vitro

Incubation of $\mathrm{ZG}$ cells for $4 \mathrm{~h}$ with AngII $\left(10^{-8} \mathrm{M}\right)$, or $\mathrm{KCl}\left(10^{-2} \mathrm{M}\right)$ enhanced aldosterone release (Fig. 2A, $P<0.05$ or 0.01$)$. Incubation of $\mathrm{KCl}$ and $\mathrm{CPA}\left(10^{-5} \mathrm{M}\right)$ with amphetamine $\left(10^{-6}\right.$ or $\left.10^{-5} \mathrm{M}\right)$ for $4 \mathrm{~h}$ caused dose proportionally dependent increment of aldosterone released from $\mathrm{ZG}$ cells (Fig. $2 \mathrm{~A}, P<0.05$ ). Although amphetamine did not increase vehicle or AngII-induced aldosterone release from $\mathrm{ZG}$ cells after $4 \mathrm{~h}$, amphetamine $\left(10^{-5} \mathrm{M}\right)$ increased vehicle or AngII-induced aldosterone release after $24 \mathrm{~h}$ (Fig. $2 \mathrm{~B}, P<0.05$ or 0.01 ).

\section{In Vivo Study}

Effects of Intraperitoneally Injected Amphetamine, with ACTH, Forsolin, 8- Br-cAMP, or H89, on the Release of Corticosterone by Rat ZFR Cells in Vivo

Incubation of ZFR cells (from group 1) for $1 \mathrm{~h}$ with ACTH $\left(10^{-9} \mathrm{M}\right)$, forskolin $\left(10^{-5} \mathrm{M}\right)$, or 8- Br-cAMP $\left(10^{-4} \mathrm{M}\right)$ enhanced corticosterone release (Fig. 3, $P<0.01$ ) but suppressed corticosterone release (Fig. 3, $P<0.01)$ when incubated with H89 $\left(10^{-6} \mathrm{M}\right)$ (Fig. 3, $P<0.01)$. Amphetamine increased basal corticosterone release from ZFR cells (from group 3) (Fig. 3, $P<0.01$ ). ZFR cells (from group 2 or 3 ) incubated with ACTH, forskolin, 8-Br-cAMP, or H89 showed increment of corticosterone release (Fig. $3, P<0.05$ or 0.01 ).
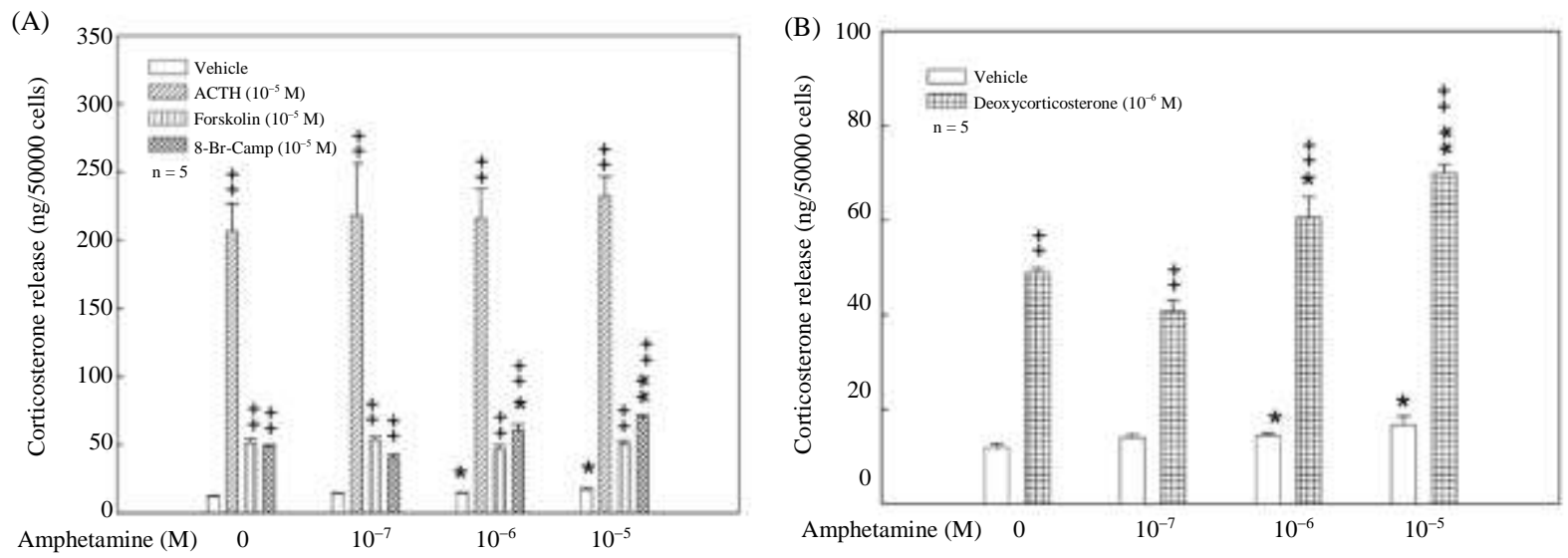

Fig. 1: Effects of amphetamine $\left(0,10^{-7}-10^{-5} \mathrm{M}\right)$ on the release of corticosterone by rat ZFR cells in vitro in response to the action of (A) ACTH $\left(10^{-9} \mathrm{M}\right)$, forskolin $\left(10^{-5} \mathrm{M}\right), 8$ - Br-cAMP $\left(10^{-5} \mathrm{M}\right)$ or $(\mathrm{B})$ deoxycorticosterone $\left(10^{-6} \mathrm{M}\right)$. $++: P<0.01$ as compared with vehicle group in the same amphetamine concentration. *, **: $P<0.05$ or 0.01 as compared with amphetamine equals to zero in each group. Each value represents the mean \pm SEM 

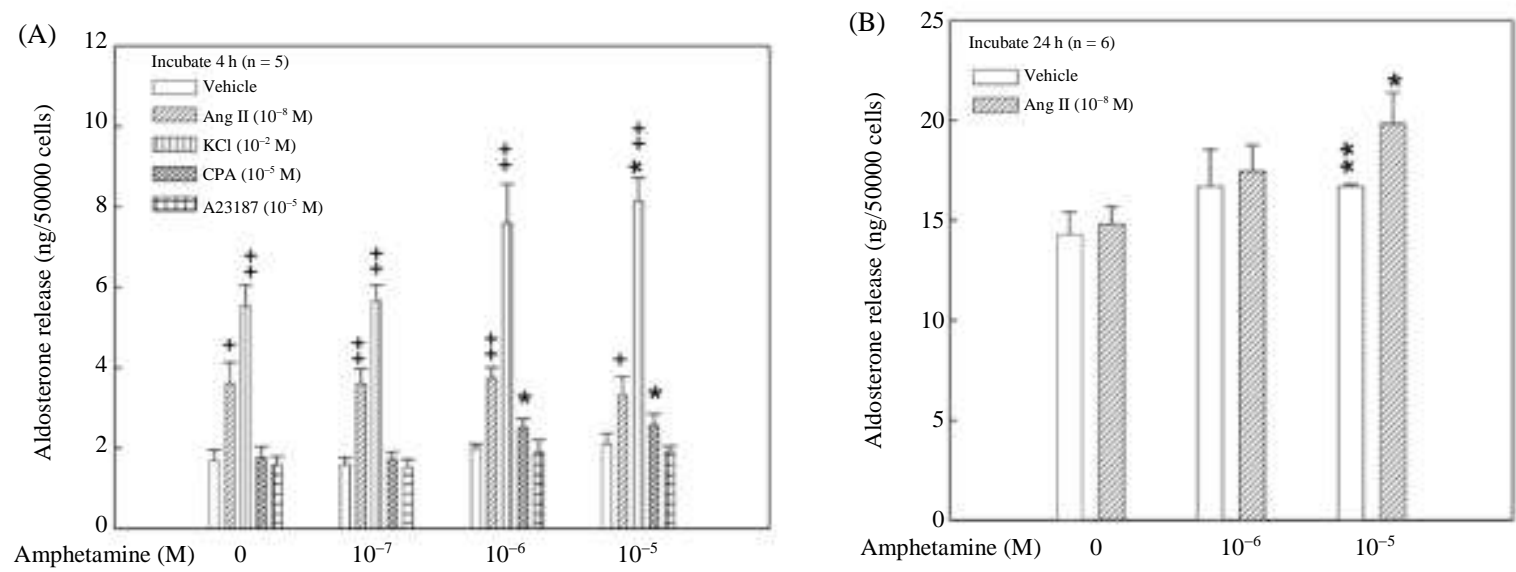

Fig. 2: Effects of amphetamine $\left(0,10^{-7}-10^{-5} \mathrm{M}\right)$ on the release of aldosterone by rat ZG cells in vitro in response to the action of AngII $\left(10^{-8} \mathrm{M}\right), \mathrm{KCl}\left(10^{-2} \mathrm{M}\right)$, CPA $\left(10^{-5} \mathrm{M}\right)$ or A23187 $\left(10^{-5} \mathrm{M}\right)$. (A) ZG cells incubated for $4 \mathrm{~h}(\mathrm{~B}) \mathrm{ZG}$ cells incubated for 24 h.,$+++: P<0.05$ or 0.01 as compared with vehicle group in the same amphetamine concentration. *, **: $P<0.05$ or 0.01 as compared with amphetamine equals to zero in each group. Each value represents the mean \pm SEM

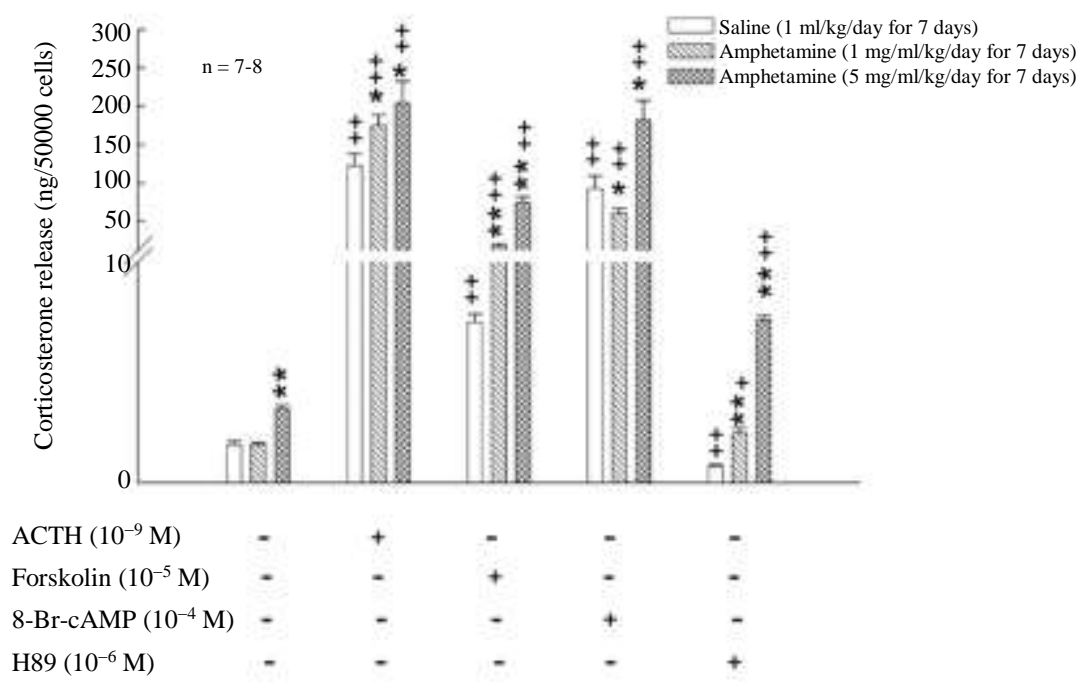

Fig. 3: Effects of amphetamine intraperitoneal injected (with saline (1 ml/kg/day, group 1), amphetamine (1 mg/ml/kg/day, group 2) or amphetamine $(5 \mathrm{mg} / \mathrm{ml} / \mathrm{kg} /$ day, group 3), respectively for 7 days) on the release of corticosterone by rat ZFR cells in vivo in response to the action of ACTH $\left(10^{-9} \mathrm{M}\right)$, forskolin $\left(10^{-5} \mathrm{M}\right), 8-\mathrm{Br}-\mathrm{cAMP}\left(10^{-4} \mathrm{M}\right)$ or H89 $\left(10^{-6} \mathrm{M}\right) .+,++: P<0.05$ or 0.01 as compared with basal in the same intraperitoneal injection amphetamine. *, **: $P<0.05$ or 0.01 as compared with intraperitoneal injecting saline in the same stimulant.

Effects of Intraperitoneally Injected Amphetamine with AngII, KCl, CPA, or A23187 on the Release of Aldosterone by Rat ZG Cells in Vivo

ZG cells (from group 1) incubated for $1 \mathrm{~h}$ with AngII $\left(10^{-8} \mathrm{M}\right), \mathrm{KCl}\left(10^{-2} \mathrm{M}\right), \mathrm{CPA}\left(10^{-5} \mathrm{M}\right)$, or A23187 $\left(10^{-5}\right.$ M) enhanced aldosterone release (Fig. $4, \quad P<0.01$ ). Amphetamine increased ZG cells (group 3) aldosterone release in response to $\mathrm{KCl}$ or CPA (Fig. 4, $P<0.05$ or 0.01 ). Amphetamine increased ZG cells (group 2 or 3 ) aldosterone release, whether basal or induced by AngII or A23187 (Fig. $4, P<0.05$ or 0.01 ).

\section{Discussion}

It is well documented that amphetamine can stimulate dopamine release in the nervous system (Dluzen and Ramirez, 1990a; 1990b; Folgering et al., 2019) to increase prolactin release (Raptis et al., 2004). Vislobokov et al. (1993) found that amphetamine at concentration $10^{-9}-10^{-7} \mathrm{M}$ can activate inward calcium current in neurons of the snail Lymnaea, but at higher concentration it inhibits. DiLullo and Martin-Iverson (1992) have shown that, in rats, the unconditioned response and conditioned locomotor response to 
amphetamine are blocked by nimodipine (L-type calcium-channel antagonist) combined with haloperidol. Cameron et al. (2015) showed that amphetamine induces dopamine transporter depolarization to activate L-type $\mathrm{Ca}^{2+}$ channel currents. Thus, amphetamine might affect prolactin and calcium ion release.

The object of this research was to explore the effects of amphetamine on adrenal cells in vitro and in vivo. In the in vitro study, broth ZFR and ZG cells were incubated with amphetamine for 4 or $24 \mathrm{~h}$. In the in vivo study, ZFR and ZG cells from rats that received intraperitoneal injections of amphetamine for 7 days were incubated for $1 \mathrm{~h}$. The amphetamine affected basal or AngII-induced aldosterone release form ZG cells at 24 $\mathrm{h}$ but not at $4 \mathrm{~h}$ in vitro.

Adrenal ZG cells producing aldosterone is controlled by AngII, $\mathrm{KCl}$ and ACTH. All inputs are mediated through increasing cAMP production and calcium mobilization. (Ehrhart-Bornstein et al., 1998; Spat and Hunyady, 2004). In ZG cells, AngII binding to the AngII receptor type 1 activates phosphoinositide-specific phospholipase $\mathrm{C}$ to generate inositol 1,4,5-triphosphate and diacylglycerol G (DAG) (Ganguly and Davis, 1994; Rasmussen et al., 1995). Calcium from an intracellular storage site was released to enhance cytosolic calcium levels and activate calcium/calmodulin-dependent protein kinase $\mathrm{C}$ to regulate sustained aldosterone production by Inositol 1,4,5-triphosphate (Ganguly and Davis, 1994; Rasmussen et al., 1995). Elevation of extracellular potassium concentration by $\mathrm{KCl}$ activates voltage-dependent calcium channels and enhances $\mathrm{Ca}^{2+}$ influx (Ganguly and Davis, 1994), which increases steroidogenesis. Together, the effects of AngII and $\mathrm{KCl}$ are likely reconciled through intracellular $\mathrm{Ca}^{2+}$. Studies have demonstrated that increasing in cytosolic $\mathrm{Ca}^{2+}$ comes out increment in aldosterone production (Payet et al., 2006; Python et al., 1995). Demaurex et al. (1992) showed that CPA induces $\mathrm{Ca}^{2+}$ secretion from Ins $(1,4,5)$ $\mathrm{P} 3$-sensitive $\mathrm{Ca}^{2+}$ stores and promotes $\mathrm{Ca}^{2+}$ influx across the plasma membrane. The ionophore A23187 increases intracellular $\mathrm{Ca}^{2+}$ levels. It also inhibits mitochondrial ATPase activity and in some cells it induces apoptosis. In this in vitro and in vivo study, AngII and $\mathrm{KCl}$ stimulated aldosterone production by ZG cells (Fig. 2 and $4, P<0.05$ or 0.01$)$. CPA or A23187 stimulated aldosterone secretion from ZG cells incubated for $1 \mathrm{~h}$ in vivo, but could not stimulate aldosterone release for $4 \mathrm{~h}$ in vitro. The reason might be cell toxicity from longterm incubation of ZG cells with CPA or A23187. Amphetamine increased basal and AngII-, $\mathrm{KCl}-$ and CPA-induced aldosterone secretion from ZG cells (Fig. 2 and $4, P<0.05$ or 0.01 ) in the in vitro and in vivo experiments, but it increased only A23187-induced aldosterone secretion from ZG cells in the in vivo study. Taken together, the results suggest that amphetamine might be stimulating calcium influx to increase aldosterone production.

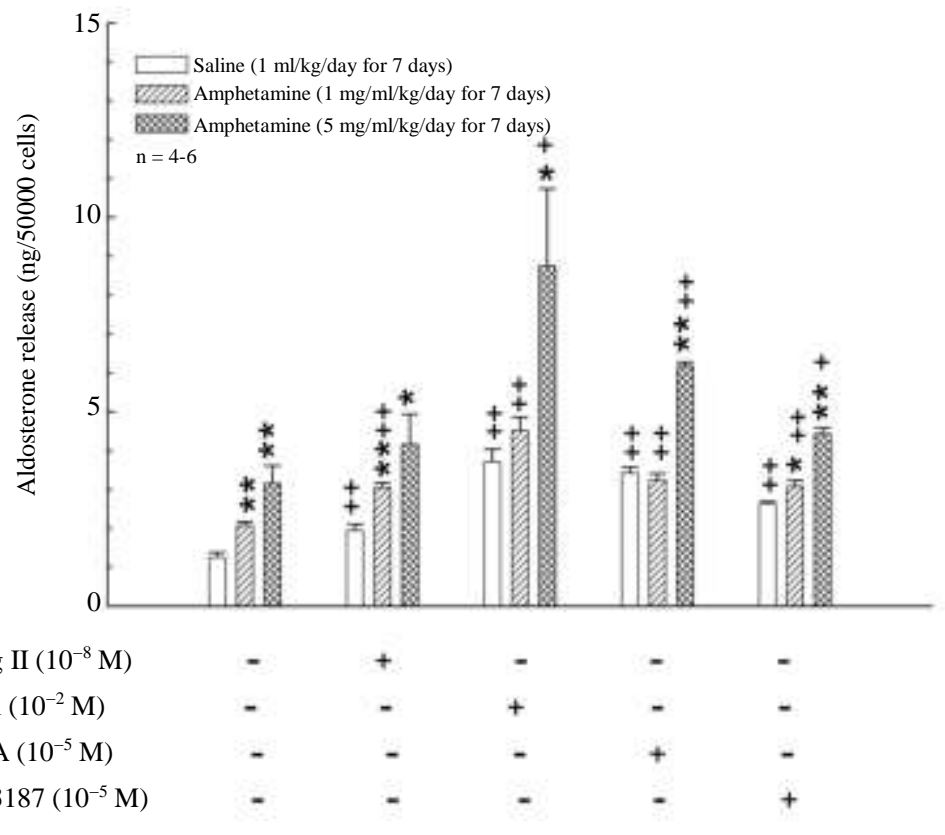

Fig. 4: Effects of amphetamine intraperitoneal injected (with saline (1 ml/kg/day, group 1), amphetamine (1 mg/ml/kg/day, group 2) or amphetamine $(5 \mathrm{mg} / \mathrm{ml} / \mathrm{kg} / \mathrm{day}$, group 3), respectively for 7 days) on the release of aldosterone by rat ZG cells in vivo in response to the action of AngII $\left(10^{-8} \mathrm{M}\right), \mathrm{KCl}\left(10^{-2} \mathrm{M}\right), \mathrm{CPA}\left(10^{-5} \mathrm{M}\right)$ or A23187 $\left(10^{-5} \mathrm{M}\right),+,++: P<0.05$ or 0.01 as compared with basal in the same intraperitoneal injection amphetamine. *, **: $P<0.05$ or 0.01 as compared with intraperitoneal injecting saline in the same stimulant 
ACTH is secreted from the anterior pituitary. It regulates acute glucocorticoid secretion and supports functions specific to cells of the adrenal cortex (Penhoat et al., 1994). ACTH mediates cAMP second-messenger systems to activate cAMPdependent Protein Kinase A (PKA) (Wong et al., 1992). Forskolin increases cAMP levels by activating adenylate cyclase to stimulate corticosterone release from ZFR cells (Uneyama et al., 1993). 8-Br-cAMP is an activator of cAMP-dependent protein kinase. In vitro and in vivo, ACTH, forskolin and 8-Br-cAMP stimulated corticosterone production from ZFR cells (Fig. 1A and 3, P<0.01). H89, a PKA inhibitor, inhibited corticosterone production by ZFR cells (Fig. $3, P<0.01)$. Amphetamine increased basal and $8-\mathrm{Br}$ cAMP-induced corticosterone secretion from ZFR cells (Fig. $1 \mathrm{~A}, 3, P<0.05$ or 0.01 ) in vitro and in vivo, but it only increased ACTH-, or forskolin-inducing corticosterone secretion from ZFR cells (Fig. 3, $P<0.05$ or 0.01 ) exposed to amphetamine in vivo. The reason might be that ACTH- or forskolin-induced corticosterone secretion reached a plateau, which blunted the effect of amphetamine. High-dose amphetamine (group 3) blunted the inhibitory effects of H89 (Fig. 3, $P<0.01$ ). Taken together, the results suggest amphetamine's stimulatory effects might be mediated through stimulation of the PKA pathway in ZFR cells.

We conclude that (1) amphetamine can stimulate rat adrenals to release corticosterone and aldosterone and (2) amphetamine might be stimulating the PKA pathway to enhance calcium influx, thereby increasing ZFR and ZG cell release of corticosterone and aldosterone.

\section{Acknowledgment}

This research supported by grants from Chinese Culture University.

\section{Author Contribution}

Ling-Ling Chang: Planned and executed all experiments, data-analysis, organization and writing of the manuscript.

Wan-Song Alfred Wun and Paulus S. Wang: Designed the research plan, organized and revised writing of the manuscript.

Cai-Yun Jian: Worked in part of experiments.

\section{Ethics}

This article is original and contains unpublished material. The corresponding author confirms that all of the other authors have read and approved the manuscript and no ethical issues involved.

\section{References}

Armario, A. (2010). Activation of the hypothalamicpituitary-adrenal axis by addictive drugs: different pathways, common outcome. Trends in Pharmacological Sciences, 31, 318-325. https://doi.org/10.1016/j.tips.2010.04.005

Anderson, K. A. \& Kane, C. D. (1998). $\mathrm{Ca} 2+/$ calmodulin-dependent protein kinase IV and calcium signaling. Biometals,11, 331-343. https://doi.org/10.1023/A:1009276932076

Bazmi, E., Mousavi, F., Giahchin, L., Mokhtari, T. \& Behnoush, B. (2017). Cardiovascular complications of acute amphetamine abuse: cross-sectional study. Sultan Oaboos University Medical Journal, 17, e31-e37. https://doi.org/10.18295/squmj.2016.17.01.007

Benitez-López, Y., Redolar-Ripoll, D., RuvalcabaDelgadillo, Y. \& Jáuregui-Huerta, F. (2019). Inhibitory control failures and blunted cortisol response to psychosocial stress in amphetamine consumers after 6 months of abstinence. Journal of Research in Medical Sciences 24, 20. https://pubmed.ncbi.nlm.nih.gov/31007690/

Berman, S., O'Neill, J., Fears, S., Bartzokis, G. \& London, E. D. (2008). Abuse of amphetamines and structural abnormalities in the brain. Annals of the New York Academy of Sciences, 1141, 195-220. https://doi.org/10.1196/annals.1441.031

Cameron, K. N., Solis, E. Jr., Ruchala, I., De Felice, L. J. \& Eltit, J. M. (2015). Amphetamine activates calcium channels through dopamine transportermediated depolarization. Cell Calcium 58, 457-466. https://doi.org/10.1016/j.ceca.2015.06.013

Carvalho, M., Carmo, H., Costa, V. M., Capela, J. P., Pontes, H., Remião, F., Carvalho, F. \& Bastos Mde, L. (2012). Toxicity of amphetamines: an update. Archives of Toxicology, 86, 1167-1231. https://doi.org/10.1007/s00204-012-0815-5

Chang, L. L., Tseng, Y. C., Lin, Y. L., Wun, W. S. A. \& Wang, P. S. (2002). Effects of S-petasin on corticosterone release in rats. Chinese Journal of Physiology, 45, 137-142. file://C:/Users/WindowS\%2010/Downloads/20141 2111824260.pdf

Chang, L. L., Wun, W. S. A. \& Wang, P. S. (2008). Effects of dehydroepiandrosterone on aldosterone release in rat zona glomerulosa cells. Journal of Biomedical Science, 15, 463-470. https://doi.org/10.1007/s11373-008-9241-3

Charmandari, E., Tsigos, C. \& Chrousos, G. (2005). Endocrinology of the stress response. Annual Review of Physiology, 67: 259-284. https://doi.org/10.1146/annurev.physiol.67.040403.1 20816 
Chen, L. Y., Huang, Y. L., Liu, M. Y., Leu, S. F., \& Huang, B. M. (2003). Effects of amphetamine on steroidogenesis in MA-10 mouse Leydig tumor cells. Life sciences, 72(17), 1983-1995. https://doi.org/10.1016/S0024-3205(03)00011-0

Demaurex, N., Lew, D. P. \& Krause, K. H. (1992). Cyclopiazonic acid depletes intracellular $\mathrm{Ca}^{2+}$ stores and activates an influx pathway for divalent cations in HL-60 cells. Journal of Biological Chemistry, 267, 2318-2324. https://doi.org/10.1016/S00219258(18)45880-2

Dilullo, S. L. \& Martin-Iverson, M. T. (1992). Calcium channel blockade interacts with a neuroleptic to attenuate the conditioning of amphetamine's behavioral effects in the rat. Biological Psychiatry, 31, 1143-1150. https://doi.org/10.1016/00063223(92)90159-W

Dluzen, D. E. \& Ramirez, V. D. (1990a). In vitro progesterone modulation of amphetaminestimulated dopamine release from the corpus striatum of ovariectomized estrogen-treated female rats: response characteristics. Brain Research, 517, $117-122$. https://doi.org/10.1016/00068993(90)91016-A

Dluzen, D. E. \& Ramirez, V. D. (1990b). In vitro progesterone modulates amphetamine-stimulated dopamine release from the corpus striatum of castrated male rats treated with estrogen. Neuroendocrinology, 52, 517-520. https://doi.org/10.1159/000125637

Ehrhart-Bornstein, M., Hinson, J. P., Bornstein, S. R., Scherbaum, W. A. \& Vinson, G. P. (1998). Intraadrenal interactions in the regulation of adrenocortical steroidogenesis. Endocrine Reviews, 19, 101-143. https://doi.org/10.1210/edrv.19.2.0326

Folgering, J. H., Choi, M., Schlumbohm, C., van Gaalen, M. M. \& Stratford, R.E. Jr. (2019). Development of a non-human primate model to support CNS translational research: demonstration with Damphetamine exposure and dopamine response. Journal of Neuroscience Methods, 317, 71-81. https://doi.org/10.1016/j.jneumeth.2019.02.005

Ganguly, A. \& Davis, J. S. (1994). Role of calcium and other mediators in aldosterone secretion from the adrenal glomerulosa cells. Pharmacological Reviews, 46, 417-447. https://pubmed.ncbi.nlm.nih.gov/7899472/

Gold, M. G. (2019). Swimming regulations for protein kinase A catalytic subunit. Biochemical Society Transactions, 2019, 47, 1355-1366. https://doi.org/10.1042/BST20190230

Hughes, S. J., Chalk, J. G. \& Ashcroft, S. J. (1990). The role of cytosolic free $\mathrm{Ca} 2+$ and protein kinase $\mathrm{C}$ in acetylcholine-induced insulin release in the clonal beta-cell line, HIT-T15. Biochemical Journal, 267, 227-232. https://doi.org/10.1042/bj2670227
Kau, M. M., Chang, L. L., Hung, P. H., Kan, S. F. \& Wang, P. S. (2000). Effects of fasting on aldosterone secretion in ovariectomized rats. Chinese Journal of Physiology, 43, 125-130. https://pubmed.ncbi.nlm.nih.gov/11132089/

Koob, G. (2008). A role for brain stress systems in addiction. Neuron, 59, 11-34. https://doi.org/10.1016/j.neuron.2008.06.012

Lo, M. J., Kau, M. M., Chen, Y. H., Tsai, S. C., Chiao, Y. C., Chen, J. J., ... \& Wang, P. S. (1998). Acute effects of thyroid hormones on the production of adrenal cAMP and corticosterone in male rats. American Journal of Physiology-Endocrinology and Metabolism, 274(2), E238-E245. https://doi.org/10.1152/ajpendo.1998.274.2.E238

Ould Amer, Y. \& Hebert-Chatelain, E. (2018). Mitochondrial cAMP-PKA signaling: What do we really know? Biochimica et Biophysica ActaBioenergetics, 1859, 868-877. https://doi.org/10.1016/j.bbabio.2018.04.005

Payet, M. D., Goodfriend, T. L., Bilodeau, L., Mackendal, C., Chouinard, L. \& Gallo-Payet, N. (2006). An oxidized metabolite of linoleic acid increase intracellular calcium in rat adrenal glomerulosa cells. American Journal of Physiology Endocrinology and Metabolism, 291, E1160-E1167. https://doi.org/10.1152/ajpendo.00108.2006

Penhoat, A., Jaillard, C. \& Saez, J. M. (1994). Regulation of bovine adrenal cell corticotropin receptor mRNA levels by corticotropin $(\mathrm{ACTH})$ and angiotensin-II (A-II). Molecular and Cellular Endocrinology, 103, R7-R10. https://doi.org/10.1016/0303-7207(94)90088-4

Phupong, V. \& Darojn, D. (2007). Amphetamine abuse in pregnancy: the impact on obstetric outcome. Archives of Gynecology and Obstetrics, 276, 167-70. https://doi.org/10.1007/s00404-007-0320-X

Python, C. P., Laban, O. P., Rossier, M. F., Vallotton, M. B. \& Capponi, A. M. (1995). The site of action of $\mathrm{Ca}^{2+}$ in the activation of steroidogenesis: studies in $\mathrm{Ca}^{2+}$-clamped bovine adrenal zona-glomerulosa cells. Biochemical Journal, 305, 569-576. https://doi.org/10.1042/bj3050569

Raptis, S., Fekete, C., Sarkar, S., Rand, W. M., Emerson, C. H., Nagy, G. M. \& Lechan, R. M. (2004). Cocaineand amphetamine-regulated transcript co-contained in thyrotropin-releasing hormone (TRH) neurons of the hypothalamic paraventricular nucleus modulates TRHinduced prolactin secretion. Endocrinology, 145, 1695-1699. https://doi.org/10.1210/en.2003-1576

Rasmussen, H., Isales, C. M., Calle, R., Throckmorton, D., Anderson, M., Gasalla-Herraiz, J. \& McCarthy, R. (1995). Diacylglycerol production, Ca2+ influx. And protein kinase $\mathrm{C}$ activation in sustained cellular responses. Endocrine Reviews, 16, 649-681. https://doi.org/10.1210/er.16.5.649 
Seibert, J., Hysek, C. M., Penno, C. A., Schmid, Y., Kratschmar, D. V., Liechti, M. E. \& Odermatt, A. (2014). Acute effects of 3,4methylenedioxymethamphetamine and methylphenidate on circulating steroid levels in healthy subjects. Neuroendocrinology, 100, 17-25. https://doi.org/10.1159/000364879

Spat, A. \& Hunyady, L. (2004). Control of aldosterone secretion: a model of convergence in cellular signaling pathways. Physiological Reviews, 84, 489-539. https://doi.org/10.1152/physrev.00030.2003

Steel, R. G. D., \& Torrie, J. H. (1960). Principles and procedures of statistics. Principles and procedures of statistics. https://www.cabdirect.org/cabdirect/abstract/1961 1601129

Uneyama, H., Uneyama, C. \& Asaike, N. (1993). Intracellular mechanisms of cytoplasmic $\mathrm{Ca}^{2+}$ oscillations in rat megakaryocyte. Journal of Biological Chemistry, 268, 168-174. https://doi.org/10.1016/S0021-9258(18)54129-6
United Nations Office on Drugs and Crime. (2010). World drug report 2010. http://www.unodc.org/unodc/en/data-andanalysis/WDR-2010.html

Vislobokov, A. I., Mantsev, V. V. \& Kuzmin, A. V. (1993). Cocaine, amphetamine and cathinone, but not nomifensine and pargyline increase calcium inward current in internally perfused neurons. Life Sciences, 52, PL261-PL265. https://doi.org/10.1016/0024-3205(93)90012-R

Wong, M., Krolczky, A. J. \& Schimmer, B. P. (1992). The causal relationship between mutations in cAMP-dependent protein kinase and loss of adrenocorticotropin-regulated adrenocortical functions. Molecular Endocrinology, 6, 1614-1624. https://doi.org/10.1210/mend.6.10.1333050

Zuloaga, D. G., Jacobskind, J. S. \& Jacob Raber, J. (2015). Methamphetamine and the hypothalamicpituitary-adrenal axis. Frontiers in Neuroscience. https://doi.org/10.3389/fnins.2015.00178 